\title{
Identification of mosquito larvicidal bacterial strains isolated from north Sinai in Egypt
}

\author{
Ferial M Rashad ${ }^{1 *}$, Waleed D Saleh ${ }^{1}$, M Nasr $^{2}$ and Hayam M Fathy ${ }^{1}$
}

\begin{abstract}
In the present study, two of the most toxic bacterial strains of Bacillus sphaericus against mosquito were identified with the most recent genetic techniques. The PCR product profiles indicated the presence of genes encoding Bin $A, B$ in $B$ and $M t x 1$ in all analyzed strains; they are consistent with protein profiles. The preliminary bioinformatics analysis of the binary toxin genes sequence revealed that the open reading frames had high similarities when matched with nucleotides sequence in the database of other B. sphaericus strains. The biological activity of $B$. sphaericus strains varied according to growing medium, and cultivation time. The highest yield of viable counts, spores and larvicidal protein were attained after 5 days. Poly (P) medium achieved the highest yield of growth, sporulation, protein and larvicidal activity for all tested strains compared to the other tested media. The larvicidal protein produced by local strains (B. sphaericus EMCC 1931 and EMCC 1932) in P medium was more lethal against the $3^{\text {rd }}$ instar larvae of Culex pipiens than that of reference strains (B. sphaericus 1593 and B. sphaericus 2297). The obtained results revealed that $P$ medium was the most effective medium and will be used in future work in order to optimize large scale production of biocide by the locally isolated Bacillus sphaericus strains.
\end{abstract}

Keywords: Bacillus sphaericus, PCR, Sequencing, Conventional media, Culex pipiens, Larvicidal activity

\section{Introduction}

Mosquito borne diseases constitute a serious health hazard to human. It has been established that, mosquito's females as blood sucking insects, are vectors of a multitude disease of man and animals in different countries through transmission of pathogenic agents. Mosquitoes are belonging to the order Diptera and family Culicidae which include the genera of medical importance, Aedes, Anopheles, Culex and Mansonia. At least 90\% of the world malaria (Anopheles), yellow fever (Aedes), dengue (Aedes), encephalitides (Aedes) and lymphatic filariasis (Aedes, Anopheles and Culex) occurs in the tropics where the environmental conditions favor insect vectors responsible for the transmission of diseases Rawlins, 1989.

Controlling insect populations with chemical insecticides has proven useful. Over time, mosquitoes developed resistance to chemical insecticides, toxicity to non target organisms, increased public awareness of the

\footnotetext{
* Correspondence: ferialrashad@yahoo.com

'Department of Microbiology, Faculty of Agriculture, Cairo University, Giza 12613, Egypt

Full list of author information is available at the end of the article
}

toxicity hazards, undermined this control strategy's efficacy. Within this scenario, biological control based on insecticidal bacteria has proven effective in controlling insect vectors. Mosquitocidal Bacillus thuringiensis subsp. israelensis and Bacillus sphaericus are used as an alternative for synthetic chemical insecticide in controlling larvae of mosquitoes over two decades. B. thuringiensis subsp. israelensis has a wider spectrum of activities against Anopheles, Culex and Aedes spp; while the target spectrum of $B$. sphaericus is restricted mainly to Culex, for a lesser extent to Anopheles and only few Aedes species. Compared to B. thuringiensis subsp. israelensis, the popular microbial mosquito control agent, $B$. sphaericus has major advantage. It appears to persist in the environment longer especially in polluted water, and thus can establish a longer lasting control of larval populations.

The toxicity of $B$. sphaericus strains is mainly attributed to the presence of binary toxin (Bin $A, \operatorname{Bin} B)$ and/ or mosquitocidal $(M t x)$ toxin genes. Binary toxin is comprised of two polypeptides of 42 - and $51-\mathrm{kDa}$ and produced during sporulation. The other group of toxins $(\mathrm{mtx} 1, \mathrm{mtx} 2, \mathrm{mtx} 3)$ is produced during vegetative 
growth. Highly toxic strains of $B$. sphaericus contains btx as principle factor or both btx and $m t x$, whereas the weakly toxic strains only contain $\mathrm{mtx}$ genes Charles et al., 1996.

Despite the excellent performance of $B$. sphaericus in the field, the presence of only the Bin toxin in spores as the major toxic moiety of commercial preparation has allowed insects to develop resistance Yuan et al., 2000 that may limit its application or necessitate rotation with other insecticides.

A program on biological control of mosquitoes, virulence prospecting and evaluation of new isolates around the world is one of the most important steps taken to determine their effect on target populations and thereby selecting the most promising strains for producing biological insecticides Litaiff et al., 2008,. Since the use of locally available effective strains are always advisable in insect control programs, the search for more effective strains able to overcome this resistance should be continued with emphasis on the isolation of more toxic strains. In an earlier study, Fathy (2002) isolated and morphologically and biochemically characterized a number of highly toxic bacterial strains against mosquito. The aim of the present investigation is to further identify two potent of the isolated strains using modern genetic techniques. Selection of the best medium that markedly supports active cell growth and high biocide production yield will also be considered.

\section{Materials and methods Microorganisms}

Two actively marked toxic strains of Bacillus sphaericus (Fathy, 2002), previously isolated from the soil of north Sinai in Egypt, identified morphologically, biochemically and assayed biologically against mosquito larvae (strains are available in Culture collection of Cairo "MIRCIN" under numbers EMCC 1931 and EMCC 1932, Agric. Faculty, Ain Shams University). They were used in the present study along with the reference strains of $B$. sphaericus 1593 and 2297 as highly toxic strains Charles et al., 1996. The reference strains, B. sphaericus 1593 and B. sphaericus 2297, were kindly provided by Prof. Dr. Y. A. Osman, Mansoura University and Prof. Dr. M. S. Foda, National Research Center, respectively.

\section{Maintenance of microorganisms}

Stock cultures were maintained in heavy spore suspensions at $4^{\circ} \mathrm{C}$ until required.

\section{Characterization of the selected local strains Polymerase chain reaction and primer sequences} Purification of genomic DNA Total DNA was prepared from bacterial strains according to the methodology of Sambrook et al. (1989). Each B. sphaericus strain was grown overnight in a $100 \mathrm{ml}$ of Luria Bertani LB medium Bertani, 1951 at $30^{\circ} \mathrm{C}$. Cells were harvested by centrifugation at $6000 \mathrm{rpm}$ and $4^{\circ} \mathrm{C}$ for $10 \mathrm{~min}$ and washed with distilled water. The pellets were frozen at $80^{\circ} \mathrm{C}$ for $1 \mathrm{~h}$ then thawed at $37^{\circ} \mathrm{C}$; resuspended in $5 \mathrm{ml}$ of solution containing $2 \mathrm{mg} / \mathrm{ml}$ lysozyme and incubated for $1 \mathrm{~h}$ at $37^{\circ} \mathrm{C}$. Then, $0.5 \mathrm{ml}$ of sodium dodecyl sulphate, SDS, (1\%) was added and the solution was left for $15 \mathrm{~min}$ at room temperature. The cell lysate was mixed with equal volume of phenol/chloroform and kept on ice for $5 \mathrm{~min}$ followed by spinning for $20 \mathrm{~min}$ at 10000 rpm and $4^{\circ} \mathrm{C}$. The supernatant that contains the DNA is mixed again with equal volume of phenol/chloroform for $5 \mathrm{~min}$ on ice to get rid of any remaining proteins and respinning for $20 \mathrm{~min}$ at $10000 \mathrm{rpm}$ and $4^{\circ} \mathrm{C}$. Afterward, 0.1 volume of sodium acetate $(3 \mathrm{M})$ and 2.5 volume of absolute ethanol was added. DNA was collected by centrifugation and the pellet was dried and washed with $70 \%$ ethanol. The DNA pellet was collected again, dried and $50 \mu \mathrm{l}$ TE buffer was added and mixed well. Finally, $10 \mu \mathrm{l}$ of RNase was added to the DNA solution and left at $37^{\circ} \mathrm{C}$ for 2 days in order to remove any contaminating RNA.

Primer According to the published sequences of the $B$. sphaericus toxin genes Shanmugavelu et al., 1995, sequences for three sets of primers of the toxin genes were selected; synthesized and obtained from Biobasic, Canada and then used for PCR amplification. The sequences of three pairs of specific primers were used to identify genes $\operatorname{Bin} A$, $\operatorname{Bin} B$ that encode binary toxins (41.9 and $51.4 \mathrm{kDa}$ ) and gene $M t x 1$ that encode mosquitocidal toxin, $100 \mathrm{kDa}$; the expected size of amplified products are shown in Table 1.

The suspensions of genomic DNAs were transferred to $25 \mu \mathrm{l}$ of PCR-reaction mixture containing $0.5 \mu \mathrm{M}$ of each primer, $0.2 \mathrm{mM}$ of each $\mathrm{dNTP}, 1 \times$ of Taq polymerase buffer, $1.5 \mathrm{mM} \mathrm{MgCl}_{2}$ and $2.5 \mathrm{U}$ of Taq polymerase (Red Hot). The PCR amplifications were performed as follows: initial denaturation of DNA at $94^{\circ} \mathrm{C}$ for $5 \mathrm{~min}, 35$ cycles comprised of $1 \mathrm{~min}$ denaturation at $94^{\circ} \mathrm{C}, 1 \mathrm{~min}$ annealing at $55^{\circ} \mathrm{C}, 2 \mathrm{~min}$ elongation step at $72^{\circ} \mathrm{C}$ followed by a final extension step at $72^{\circ} \mathrm{C}$ for seven min. Amplicons were visualized by electrophoresis on $1 \%$ agarose gel stained with ethidium bromide. The banding was visualized at short UV light Carozzi et al., 1991.

Sequence analysis The dideoxyribonucleoside chain termination procedure originally developed by Sanger et al. (1977) was employed for sequencing the doublestranded DNA obtained during the PCR. Sequencing was conducted under BigDyeTM terminator cycling condition. The reacted products were purified using Ethanol Precipitation and run using Automatic Sequencer $3730 \times 1$ (Macrogen, DNA sequencing, USA). The nucleotide sequence data of the Bin toxins open reading 
Table 1 The sequence of primers and the expected size of the amplified products.

\begin{tabular}{|c|c|c|c|c|}
\hline Primer & Sequence & Length meres & Standard & Product size \\
\hline \multirow[t]{2}{*}{$\operatorname{Bin} A$} & 5'ATGAGAAATTTGGATITATT 3' & 21 & $1593 M$ & $1.1 \mathrm{~kb}$ \\
\hline & 5'TTAGTTTTGATCATCTGTAAT 3' & 21 & $1593 \mathrm{M}$ & \\
\hline \multirow[t]{2}{*}{$\operatorname{Bin} B$} & 5'ATGTGCGATTCAAAAGACAAT3' & 21 & $1593 M$ & $1.3 \mathrm{~kb}$ \\
\hline & 5'TCACTGGTTAATTITAGGTA 3' & 20 & $1593 \mathrm{M}$ & \\
\hline \multirow[t]{2}{*}{ Mtx1 } & 5'ATGGCTATAAAAAAAGTATTA3' & 21 & $1593 \mathrm{M}$ & $2.6 \mathrm{~kb}$ \\
\hline & 5'TACTATCTAGGTTCTACACC 3' & 20 & $1593 M$ & \\
\hline
\end{tabular}

frame was submitted to the BLASTN programs search nucleotide data bases http://www.ncbi.nlm.nih.gov.

Sequencing the DNA alignments encoding binary toxins were performed according to EXPASY Proteomics Server (Expert Protein Analysis System) proteomics server of the Swiss Institute of Bioinformatics (SIB). http:// www.expasy.org. The partial DNA sequences for Bin A and B from the local strains (Bacillus sphaericus EMCC 1931 and 1932) were assigned GenBank accession nos. JN007909, JN0079010 and JN0079011, JN0079012 for B. sphaericus EMCC 1931 and B. sphaericus EMCC 1932, respectively.

\section{Protein profile analysis}

The most commonly method of analysis and separation of protein is sodium dodecyle sulfate-polyacrylamide gel electrophoresis (SDS-PAGE) which based on the relative molecular weight of protein Laemmli, 1970. For each strain of B. sphaericus, protein analysis was made for both 18 and $120 \mathrm{~h}$ cultures. Samples of whole cultures were centrifuged at $6000 \mathrm{rpm}$ and $4^{\circ} \mathrm{C}$ for $10 \mathrm{~min}$; then the pellets were harvested and washed three times using distilled water $\left(6,000 \mathrm{rpm} / 10 \mathrm{~min} / 4^{\circ} \mathrm{C}\right)$. The pellets resuspended in an equal volume of loaded buffer followed by scratching and heating at $100^{\circ} \mathrm{C}$ for $5 \mathrm{~min}$., the extracts were clarified by centrifugation at $10,000 \mathrm{rpm}$ for $10 \mathrm{~min}$; the supernatants were injected in polyacrylamide gel for protein separation.

The separating gel solution was prepared and poured into the gel apparatus between the cleaned glass plates. The gel solution was immediately overlaid with water and allowed to polymerize at room temperature for 45$60 \mathrm{~min}$, then water was removed. Stacking gel solution was prepared, poured over the separating gel and allowed to polymerize for 30-45 min. Polyacrylamide gels were stained in Coomassie brilliant blue solution with gentle shaking for up to $3 \mathrm{~h}$ at room temperature.

Separation was done using Mini-Protein II electrophoresis unit at $200 \mathrm{~V}$, constant voltage for approximately $45 \mathrm{~min}$ in SDS-electrophoresis buffer. The gel was destained by incubation in several volumes of Coomassie brilliant blue destain solution for up to $8 \mathrm{~h}$ at room temperature. Proteins were detected as bluestained bands against clear background.
Protein profile analysis was carried out using Gel Documentation System (Alpha Image 2000), Germany.

\section{Cell growth and toxin production by bacterial strains in}

\section{various cultivation media}

B. sphaericus strains were grown on nutrient agar slants at $30^{\circ} \mathrm{C}$ for $72 \mathrm{hr}$. Seed cultures were carried out following the technique of Obeta and Okafor (1983). The slant cultures were washed with $5.0 \mathrm{ml}$ sterile distilled water, which were then added to $250 \mathrm{ml}$ flasks containing $50 \mathrm{ml}$ nutrient broth. The flasks were placed on a rotary shaker at $200 \mathrm{rpm}$ and incubated for $24 \mathrm{hr}$ at $30^{\circ}$ C. From these first- passage seed cultures, $5.0 \mathrm{ml}$ were used to inoculate similar seed flasks and treated as above for $18 \mathrm{~h}$.

Five conventional laboratory media that have been recommended as reference media by many authors were used for B. sphaericus production as follow: Glucose-Glutamate-Salts- EDTA (GGSE medium), Chan et al. (1972), g/l, glucose 5, monosodium glutamate 10, $\mathrm{K}_{2} \mathrm{HPO}_{4} \quad 0.5, \mathrm{KH}_{2} \mathrm{PO}_{4} \quad 0.5, \mathrm{MgSO}_{4} .7 \mathrm{H}_{2} \mathrm{O} \quad 0.2$, FeS$\mathrm{O}_{4} .7 \mathrm{H}_{2} \mathrm{O} 0.01, \mathrm{MnSO}_{4} .4 \mathrm{H}_{2} \mathrm{O} 0.01, \mathrm{ZnSO}_{4} .7 \mathrm{H}_{2} \mathrm{O} 0.013$, $\mathrm{CaCl}_{2}$ 0.025, thiamine 0.0005 , biotin $1 \mu \mathrm{g}$, EDTA 25 $\mu \mathrm{g} / \mathrm{ml}$; Nutrient Yeast Extract Salt (NYS medium) without glucose, Yousten and Davidson (1982), g/l, peptone 5 , beef extract 3, yeast extract $0.5, \mathrm{MnCl}_{2}$ $0.01, \mathrm{CaCl}_{2}$ 0.1, $\mathrm{MgCl}_{2}$ 0.2; Poly (P medium), Bourgouin et al. (1984),, g/l, peptone 5, beef extract 5, yeast extract 10, glycerol 10, NaCl, 3; Acetate Yeast Extract (AYE medium), Sasaki et al. (1998), g/l, sodium acetate 5.45 , yeast extract $10, \mathrm{MnCl}_{2} .4 \mathrm{H}_{2} \mathrm{O} 0.02, \mathrm{CaCl}_{2} .2 \mathrm{H}_{2} \mathrm{O}$ $0.2, \mathrm{MgCl}_{2} .6 \mathrm{H}_{2} \mathrm{O}, 1.02, \mathrm{KH}_{2} \mathrm{PO}_{4} 0.5$ and Luria Bertani (LB medium), Poopathi et al. (2002) g/l, peptone 5, yeast extract $2.5, \mathrm{NaCl} 5$. The $\mathrm{pH}$ of all media was adjusted to $7.1 \pm 0.1$ with $1 \mathrm{~N} \mathrm{NaOH}$, and the media were dispensed in flasks as $20 \% \mathrm{v} / \mathrm{v}$ and sterilized at $121^{\circ} \mathrm{C}$ for $20 \mathrm{~min}$.

Production flasks of each medium were inoculated in triplicate with $1.0 \mathrm{ml}(2 \% \mathrm{v} / \mathrm{v}$, Prabakaran et al., 2007) of a second passage seed culture of each $B$. sphaericus strains and allowed to grow at $30^{\circ} \mathrm{C}$ for 5 days on a rotary shaker (Cole Parmer, 51604) at $200 \mathrm{rpm}$. Culture samples were drawn from each culture medium at 0,1 , 3 and 5 days intervals. 
Total viable and spore counts Serial decimal dilutions of culture samples were prepared; $1 \mathrm{ml}$ of each dilution (in triplicates) was added to Petri dish, followed by addition of nutrient agar medium. For spore counts, the serial dilutions of culture samples were pasteurized at $80^{\circ} \mathrm{C}$ for $15 \mathrm{~min}$ before plating. Plates were incubated at $30^{\circ} \mathrm{C}$ for $48 \mathrm{~h}$ and the developing B. sphaericus colonies were counted and expressed as $\mathrm{cfu} / \mathrm{ml}$ and/or spores $/ \mathrm{ml}$. The $\mathrm{pH}$ of culture samples were estimated using a digital pH meter (JEN WAY, 3305).

Biochemical studies and toxicity bioassay Whole culture samples for each strain on different media were centrifuged at $6000 \mathrm{rpm}$ and $4^{\circ} \mathrm{C}$ for $10 \mathrm{~min}$ and washed twice with distilled water. The pellets resuspended in distilled water and used for protein determination and toxicity bioassay.

Protein determination Protein extracts were prepared by adding $25 \mu \mathrm{l}$ of $2 \mathrm{M} \mathrm{NaOH}$ solution to each ml suspension followed by incubation at $37^{\circ} \mathrm{C}$ for $3 \mathrm{hr}$ Sasaki et al., 1998,. After centrifugation and extraction as mentioned above, protein concentrations in the clarified supernatant were determined using the technique of Bradford (1976) with bovine serum albumin (BSA, Sigma) as standard.

\section{Bioassay against Culex pipiens larvae}

The Culex pipiens $3^{\text {rd }}$ instar larvae were obtained from mosquito rearing laboratory in Research Institute of Medical Entomology, Ministry of Health. Serial dilutions of the previously resuspended pellets were prepared in distilled water, and then one $\mathrm{ml}$ of each dilution was added to $100 \mathrm{ml}$ distilled water in $200 \mathrm{ml}$ plastic cups. Twenty, $3^{\text {rd }}$ instar larvae of $C$. pipiens were placed in each cup and suitable amount of larval food was added (ground dried bread: dried Brewer's yeast as 2:1). Experiments were conducted at room temperature of $28^{\circ} \mathrm{C} \pm 2$. Each experiment included 3 concentrations in triplicates, as well as appropriate control. Larval mortality was scored after $48 \mathrm{~h}$ and corrected (if needed) for control mortality using Abbott's formula Abbott, 1925.

\section{Statistical analysis}

All data were statistically analyzed using Factorial ANOVA test MSTAT-C Version 4, 1987

\section{Results \\ Characterization of the locally isolated strains Detection of toxin genes by Polymerase chain reaction (PCR)}

The expected sizes of the PCR products were 1.1, 1.3 and $2.6 \mathrm{~kb}$ for $\operatorname{Bin} A, \operatorname{Bin} B$ and $M t x 1$ toxin genes, respectively. As shown in Figure (1a, b and 1c), the primer designed for each gene amplified the target toxin gene as the amplicon obtained was of the expected size. The PCR product profiles of the local strains (Bacillus

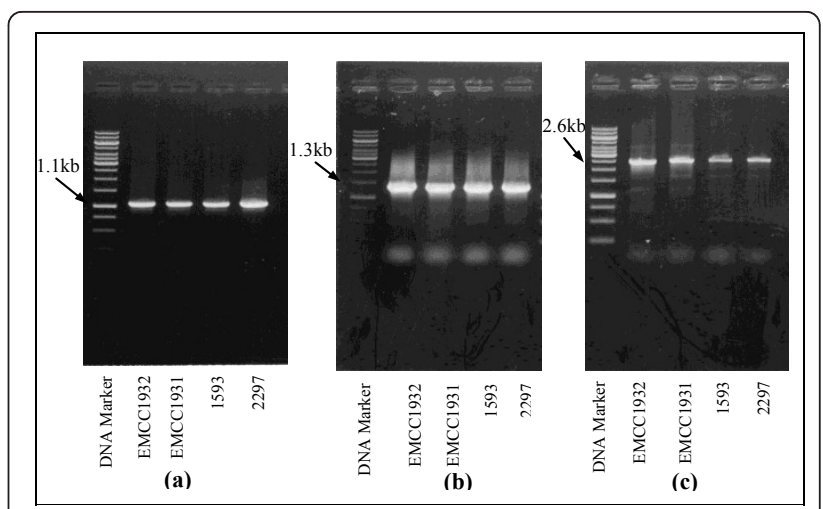

Figure $1 \mathrm{PCR}$ product profiles of Bacillus sphaericus strains.

sphaericus EMCC 1931 and EMCC 1932) are identical to those of the reference strains, B. sphaericus 1593 and B. sphaericus 2297. Analysis of these profiles proved that both the standard and local strains harbor the Bin $A, \operatorname{Bin} B$ and $M t x 1$ genes encoding Bin A 42-, Bin B 51and Mtx1 100-kDa proteins.

\section{Sequencing of the binary toxin gene operons from local strains}

The preliminary bioinformatics analysis of the binary toxin genes sequence revealed that the open reading frames had high similarities when matched with nucleotides sequence in the database of other B. sphaericus strains. Based on linear DNA sequences of Bin A (737 bp and $348 \mathrm{bp}$ ) and Bin B (513 bp and $373 \mathrm{bp}$ ) of local strains (B. sphaericus EMCC 1931 and EMCC 1932) respectively, the phylogenetic trees (Figure $2 \& 3$ ) were constructed. Genetically, Bin $A$ and $B$ gene operons from the local strain $B$. sphaericus EMCC 1931 were found to be close to those from other B. sphaericus strains with at least $94 \%$ similarities. However, the sequences of binary toxin gene operons from the other local strain B. sphaericus EMCC 1932 revealed lower similarity (only $81 \%$ for $\operatorname{Bin} A$ and $89 \%$ for $\operatorname{Bin} B$ genes). The locus sequences of DNA linear Bin A and Bin B binary toxin genes, partial cds were deposited in the GenBank under the accession numbers JN007909, JN0079010, and JN0079011, JN0079012 for B. sphaericus EMCC 1931 and EMCC 1932, respectively.

Derived from the nucleotide sequence of the DNA fragments encoding the 42 - and $51-\mathrm{kDa}$ toxin proteins of the local strains (B. sphaericus EMCC 1931 and EMCC 1932), the amino acid sequences were deduced and shown below the nucleotide sequence; the constructed similarity trees were drawn (Figure $4 \& 5$ ). It is apparent that the 42 - and $51-\mathrm{kDa}$ toxin proteins in local strains have high levels of similarity when matched with protein in binary toxins in the database. A significant homology of $95 \%$ was found between the amino acid sequence of the B. sphaericus EMCC 1931 protein and 
Bacillus sphaericus binA, bin B genes and transposase pseudogene

$\triangle$ Lysinibacillus sphaericus strain ISPC- 8 binary toxin A (binA) gene, complete cds

Lysinibacillus sphaericus $\mathrm{C} 3 \mathbf{4 1}$, complete genome

Lysinibacillus sphaericus $\mathrm{C} 3-41$ plasmid pBsph, complete sequence

Bacillus sphaericus gene for $41.9 \mathrm{kDa}$ toxin (H- flagellar $\mathrm{H} 25$ antigen group)

0

Bacillus sphaericus binA, bin B genes and transposase pseudogene, strain 2297

Bacillus sphaericus bint operon

Bacillus sphaericus binA gene, strain LP1-G

Bacillus sphaericus genes for $51.4 \mathrm{kD}$ and $+1.9 \mathrm{kD}$ toxin proteins

Bacillus sphaericus bina gene, strain 9002

s Bacillus sphaericus bina gene, strain Pr1

Bacillus sphaericus binA gene, strain lA B881

Eacillus sphaericus binA gene, strain IA E872

Bacillus sphaericus isolate wB M 1-1-13 binary toxin B (bin B) and binary toxin A (binA) genes, complete cds

B.sphaericus larvicidal toxin (against Culex and Anopheles) m RNA, complete cds

Eacillus sphaericus $41.9 \mathrm{kDa}$ toxin gene

B.sphaericuso 51.4 and $41.9 \mathrm{Kd}$ lanvicidal protein genes, complete cds

EMCC1931

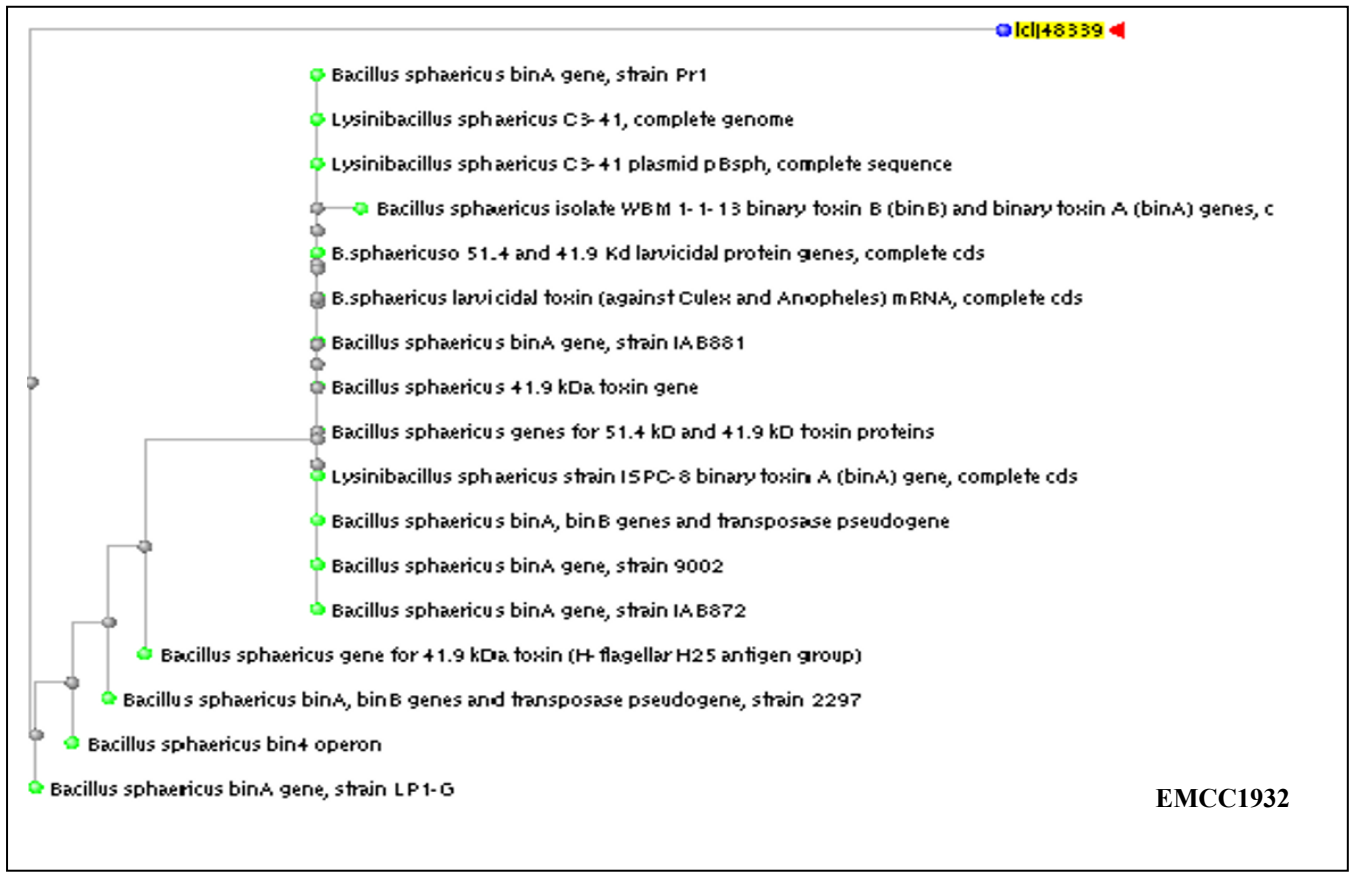

Figure 2 Phylogenetic trees of the DNA fragments of Bin A genes encoding 42-kDa toxin of local strains of $B$. sphaericus.

the $42-\mathrm{kDa}$ toxin over a stretch of 283 amino acids. This percentage of identity was markedly decreased to $81 \%$ in case of the protein produced from B. sphaericus EMCC 1932 strain over 254 amino acids. With respect to $51-\mathrm{kDa}$ toxin protein, the amino acid sequence obtained from the B. sphaericus EMCC 1931 protein recorded a similarity percentage of 94 , overall 279 amino acids. On the other hand, this similarity decreased to record $89 \%$ with the second strain, $B$. sphaericus EMCC 1932, with 268 amino acids. 

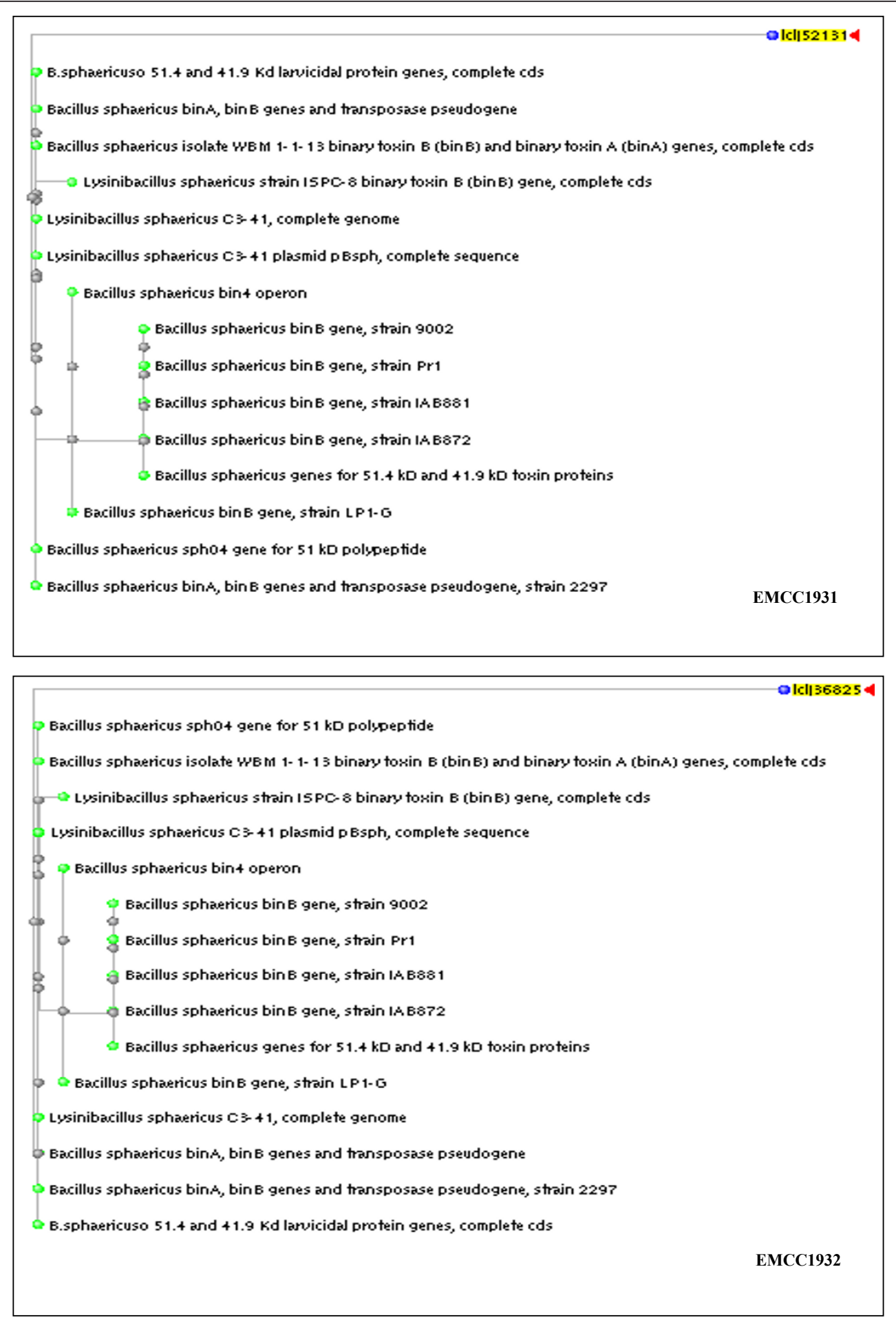

Figure 3 Phylogenetic trees of the DNA fragments of Bin B genes encoding 51-kDa toxin of local strains of $B$. sphaericus.

\section{Analysis of protein profiles by SDS-PAGE}

The protein patterns of the local (B. sphaericus EMCC 1931 and EMCC 1932) and reference (B. sphaericus 1593 and B. sphaericus 2297) strains resulting from SDS-PAGE (Figure 6) showed that numerous molecular weights of proteins were detected for both 18 and $120 \mathrm{~h}$ cultivation. The protein fractions separated along 9 - > 17 bands with molecular weights ranged from 20 - to 139- kDa were quantitatively differed as estimated from their migration in SDS-PAGE, densitographs (Figures 7 


\section{EMCC1931, 42 kDa \\ EMCC1931, 51 kDa}

tttccgcaggaagtcattcgcgctttggatttttataatagcgagtatcctttctgtata $\begin{array}{lllllllllllllllllllll}F & P & Q & E & V & I & R & A & L & D & F & Y & N & S & E & Y & P & F & C & I\end{array}$ catgcaccctcagcccctaatggggatatcatgacagaatctgtagcagagaaataat caatattttattttttttcctactgatgatggtcgagtaattattgcaataggcataat $\begin{array}{llllllllllllllllllll}Q & Y & F & I & F & F & P & T & D & D & G & R & V & I & I & A & N & R & H & N\end{array}$ gggtccgtttttaccggagaagccacaagtgtagtatcagatatctatactggtagccca

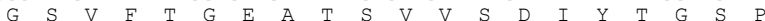
ttacagtttttagagaggtcaaagaactatggcaacttattatttagcgatacaaaat $\begin{array}{llllllllllllllllllll}L & Q & F & F & R & E & V & K & R & T & M & A & T & Y & Y & L & A & I & Q & N\end{array}$ $\begin{array}{llllllllllllllllllll}\mathrm{P} & \mathrm{E} & \mathrm{S} & \mathrm{A} & \mathrm{T} & \mathrm{D} & \mathrm{V} & \mathrm{R} & \mathrm{A} & \mathrm{L} & \mathrm{E} & \mathrm{P} & \mathrm{H} & \mathrm{S} & \mathrm{H} & \mathrm{E} & \mathrm{L} & \mathrm{P} & \mathrm{S} & \mathrm{R}\end{array}$ ctttattacactaacaatattgaaataatagcaacatattaatttctaataaggaacaa

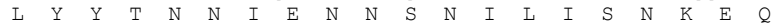
atatatttaaccttgccttcacttccagaaaacgagcaataccctaaactccagtatta $\begin{array}{llllllllllllllllllll}I & Y & L & T & L & P & S & L & P & E & N & E & Q & Y & P & K & T & P & V & L\end{array}$ agcggtatcgatgatataggacctaatcaatcagagaatcaataataggaagtactctt $\begin{array}{llllllllllllllllllll}5 & G & I & D & D & I & G & P & N & Q & S & E & K & S & I & I & G & S & T & L \\ & \end{array}$ $\begin{array}{llllllllllllllllllll} & \mathrm{P} & \mathrm{C} & \mathrm{I} & \mathrm{M} & \mathrm{V} & \mathrm{S} & \mathrm{D} & \mathrm{F} & \mathrm{I} & \mathrm{S} & \mathrm{L} & \mathrm{G} & \mathrm{E} & \mathrm{R} & \mathrm{M} & \mathrm{N} & \mathrm{T} & \mathrm{T} & \mathrm{P}\end{array}$ tattattatgtaaagccccctccatattgccaaaatctgagctccgcgctctttcccccc $\begin{array}{llllllllllllllllllllll}Y & Y & Y & V & K & P & P & P & Y & C & Q & N & L & S & S & A & L & F & P & P\end{array}$ ggctctcagacgaatataacgacacctccggtaccctggttctctcaattaaccatg cctgacgggattcactgaccactcccattcacacttttatcttatggatctcaattaaac $\begin{array}{llllllllllllllllllll}P & D & G & I & H & - & P & L & P & F & T & L & L & S & Y & G & S & Q & L & N\end{array}$ ccttccccttccotcgecetttttaatcattttcataacacgacttctcctcctac $\begin{array}{lllllllllll}H & N & T & T & S & P & P & T\end{array}$ ttctttttcecc

F F F P

\section{EMCC1932, 42 kDa}

ttttccgaagggaagggtgtcgcgcttggatttttataatagcgagtatcctttctgtat $\begin{array}{cccccccccccccccccccc}\text { F } & \text { P } & \text { K } & \text { G } & \text { R } & \text { V } & \text { S } & \text { R } & \text { F } & \text { G } & \text { F } & \text { L } & - & - & \text { R } & \text { V } & \text { S } & \text { F } & \text { L } & \text { Y } \\ \text { acaagecccctcagcccctaatgggggatatcatgacagaatctgtacctcagaaaatgc }\end{array}$

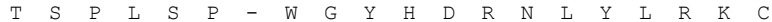
tccatatattatcccttatctaccgatgatggtcgagtaattattgcggaccggctaaa

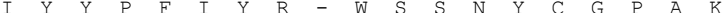
cgggccetctttaccttcaagccataagtggggtatcatatgtttacaatgggagca $\begin{array}{llllllllllllllllllll}R & A & L & F & Y & L & S & S & H & K & W & G & I & I & C & L & Q & W & E & H\end{array}$ attttcccatttataatagcccattacaactgtgtctagcttacatatctacgagtat gggtgcccattaaagagtgatgtccgtgtatcagagaccactcctgatcgcccatgcca G C P I K E - C P C I R D H S - S P M P tcccgtctatgccgtatgacattattctgtttctttgttccctccctaatattgaccca

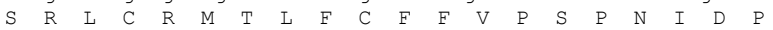
atacatctcggaccttttttcagaatatccacatcatcgccetctatcatctatcata $\begin{array}{llllllllllllllllllll}\text { I } & H & \text { L } & G & \text { P } & \text { F } & \text { F } & \text { Q } & \text { N } & \text { I } & \text { H } & \text { I } & \text { I } & \text { A } & \text { L } & \text { L } & \text { S } & \text { S } & \text { I } & \text { I }\end{array}$ $\begin{array}{lllllllllllllllllllll}L & C & L & L & Q & M & L & P & D & Q & W & S & S & R & A & D & Y & P & - & L\end{array}$ ctccttttcaacctcgcgttccttactgtggactgttcgcatagcccggtcctttcctc $\begin{array}{lllllllllllllllllllll}L & L & F & Q & P & R & V & P & Y & C & G & L & F & A & - & P & G & P & F & \text { I }\end{array}$ ggtacagagcatcgacgttatattggttttggcgggagcgcataatttgggcttatgttg $\begin{array}{llllllllllllllllllllllllllllllll}G & T & E & H & R & R & Y & I & G & F & G & G & S & A & - & F & G & \text { L } & M & \text { L }\end{array}$ cactgcatcatattcatcatcatctggcgtagccatcttacttccctccctagtatat $\begin{array}{llllllllllllllllllllllll}H & C & I & I & F & I & I & I & W & R & S & H & L & T & S & L & P & K & Y & I\end{array}$ tccetaggettace

S L G F T

Figure 4 Nucleotide sequence of the DNA fragment encoding 42 kDa and 51 kDa toxins of local strains of $B$. sphaericus EMCC1931 and EMCC1932. The predicted amino acid sequence is given in the single-litter code.

\&8). The high molecular mass protein bands over the range of 128 - to 139 - kDa were detected in all lanes from 18 and $120 \mathrm{~h}$ cultures, however, disappeared after 120 h only in the culture of B. sphaericus EMCC 1931. Also, bands of protein fractions with $110-$ to $125-\mathrm{kDa}$ were found in the lanes of all cultures during the vegetative growth and after the completion of sporulation. Only two bands of protein fractions with molecular weight 100 - to $107-\mathrm{kDa}$ were found in the lane of $18 \mathrm{~h}$ culture of the strain B. sphaericus EMCC 1931. An additional bands at about 90 - 94-, 82 - 85-, 67- 78-, 54 -
作 $\begin{array}{llllllllllllllllllll}P & V & Q & W & E & E & F & T & N & Y & P & L & N & T & T & P & T & S & L & N\end{array}$ ataaccttccagaaatatcaaaaaattttataaccttaagaataaatattcacggaat $\begin{array}{llllllllllllllllllll}Y & N & L & P & E & I & S & K & K & F & Y & N & L & K & N & K & Y & S & R & N\end{array}$ gttatggtttatcaaaaaccgaatttccttcaagtatcgaaaattgcccatctaacgaa $\begin{array}{llllllllllllllllllll}G & Y & G & L & S & K & T & E & F & P & S & S & I & E & N & C & P & S & N & E\end{array}$ ttcaataatgtatgataataaagatcctcgattcttgattcggtttttattagatgat $\begin{array}{lllllllllllllllllllll} & S & I & M & Y & D & N & K & D & P & R & F & L & I & R & F & L & L & D & D\end{array}$ gtagatatattattgcagatagagacgatggagaagtttttgatgaagcacctacttat $\begin{array}{lllllllllllllllllllll}G & R & Y & I & I & A & D & R & D & D & G & E & V & F & D & E & A & P & T & Y \\ & & & & & & & \end{array}$ G ttgagcaggtaggtagtggagattatattacgggagagcaattttttcaattctataca

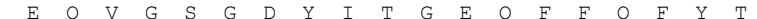
aaataaaccatctgtattgccaacctgcatggcccttgactgcaagacaatactccta

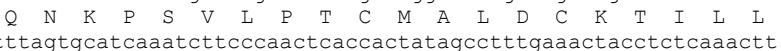
$\begin{array}{llllllllllllllllllll}F & S & A & S & N & L & P & N & S & P & L & - & P & L & K & L & P & L & K & L\end{array}$ Y P N I P V Y R A T I S - I P O P N L T cerctacatgtccctaccttcactctacttgacgacccttatcttattatctctcttgga $\begin{array}{llllllllllllllllllll}P & L & H & V & P & T & F & T & L & L & D & D & P & Y & L & I & I & S & L & G\end{array}$ ttttccctccttttccccatcccgetctaccccctcctctcatatctcgattagcat $\begin{array}{lllllllllllllllllllll}F & S & L & L & F & P & Q & S & R & S & T & P & L & L & S & Y & L & D & - & H\end{array}$ tetctcaattcttctcacgacccaccttccctgaatcaatcat

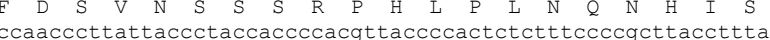
$\begin{array}{llllllllllllllllllll}\mathrm{P} & \mathrm{N} & \mathrm{P} & \mathrm{Y} & \mathrm{Y} & \mathrm{P} & \mathrm{T} & \mathrm{T} & \mathrm{P} & \mathrm{R} & \mathrm{Y} & \mathrm{P} & \mathrm{T} & \mathrm{L} & \mathrm{F} & \mathrm{P} & \mathrm{R} & \mathrm{L} & \mathrm{P} & \mathrm{L}\end{array}$ cacc

\section{EMCC1932, 51 kDa}

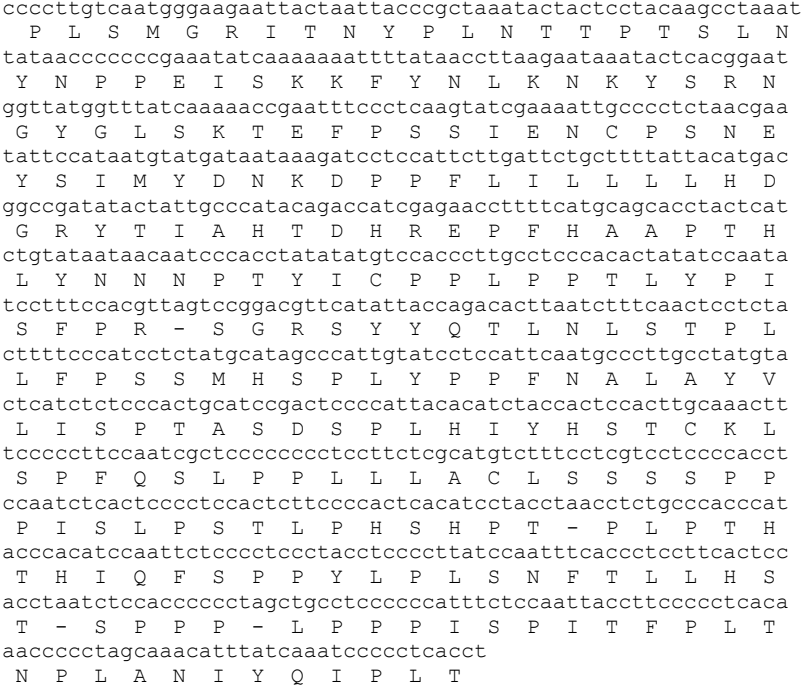




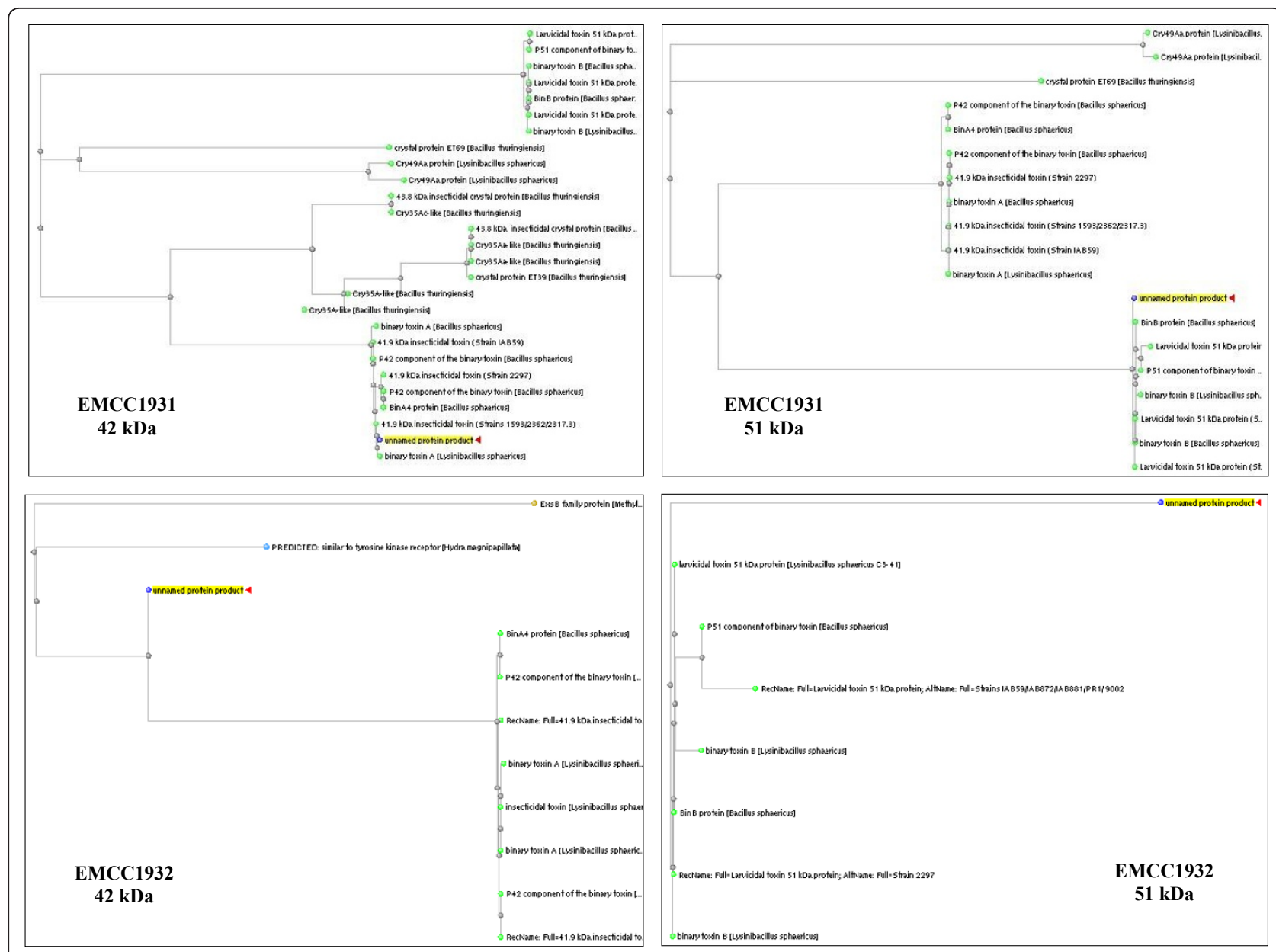

Figure 5 Similarity trees of the DNA fragments of Bin A and Bin B genes encoding 42-kDa and 52-kDa toxins of local strains of $B$. sphaericus EMCC1931 and EMCC1932.

however no significant differences could be observed between the other tested media. Increasing cultivation time up to $72 \mathrm{~h}$ resulted in increasing growth yield; $\mathrm{P}$ medium was still the best medium supporting the growth of different B. sphaericus strains (about $43-300$ fold over the other tested media). After 5 days and at the end of the cultivation course, the viable counts of different strains, to some extent, remained stable in $\mathrm{P}$ medium, but they increased in the other tested media with multiplication rates ranged from 1.25 to 58.3 fold. NYS medium attained the highest significant yield of 1.1 $-1.3 \times 10^{9} \mathrm{cfu} / \mathrm{ml}$ and stand with $\mathrm{P}$ medium without significant differences. GGSE medium $\left(2.0 \times 10^{8}-1.0 \times\right.$ $\left.10^{9} \mathrm{cfu} / \mathrm{ml}\right)$, LB medium $\left(1.2-2.7 \times 10^{8} \mathrm{cfu} / \mathrm{ml}\right)$ and AYE medium $\left(1.0-1.8 \times 10^{8} \mathrm{cfu} / \mathrm{ml}\right)$ came after (Figure 9).

Sporulation rate was generally at low levels after $24 \mathrm{~h}$ in all tested media, $\mathrm{P}$ medium recorded the lowest significant rate $(1.3-1.7 \%)$, although it attained the highest viable spore counts. After $72 \mathrm{~h}$, sporulation rate was still low (Figure 9) and significant differences were observed within the tested strains in $\mathrm{P}$ medium and between $\mathrm{P}$ medium and the other tested media. Consequently, the maximum yield of spores was reached at the end of the cultivation time in both $\mathrm{P}$ medium and NYS medium $\left(1.0-1.4 \times 10^{9}\right.$ spores $\left./ \mathrm{ml}\right)$ followed by GGSE medium $\left(1.1-8.0 \times 10^{8}\right.$ spores $\left./ \mathrm{ml}\right)$, however, the highest significant sporulation rate $(88.5-100 \%)$ was obtained in NYS medium followed by $\mathrm{P}$ medium and GGSE medium (71.4 - 93.3\%), (40.0 - 80\%) in that order. There were no significant differences between the local (B. sphaericus EMCC1931) and the reference (B. sphaericus 2297) strains but they varied significantly with the other tested strains (Figure 9).

Protein was produced after $24 \mathrm{~h}$ in the cultivation media except in GGSE medium and AYE medium, whereas it was produced lately. Protein was in increasing order along the cultivation course. The highest significant quantities were attained in $\mathrm{P}$ medium by the local strains (B. sphaericus EMCC 1931 and EMCC 


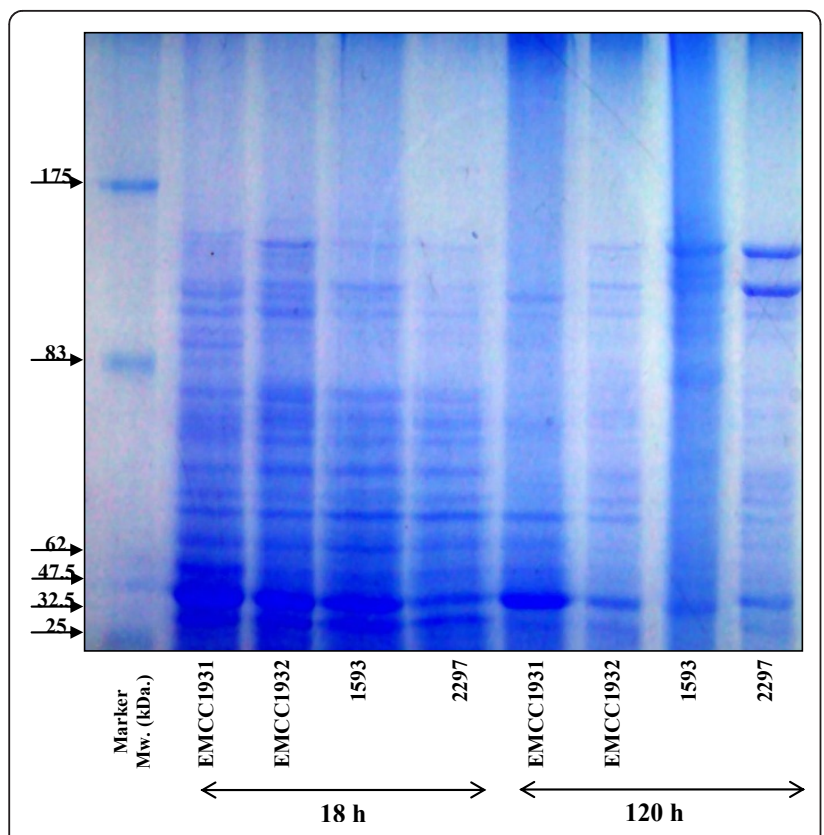

Figure $6 \mathrm{Gel}$ electrophoresis of crude toxin extracts from $B$. sphaericus strains. Molecular weight standards in kDa: 175, 83, 62, $47.5,32.5$ and 25 .

1932) by 5 days (Figure 10a). Generally, the quantities of produced protein differed significantly among the tested media and strains along the cultivation time. Local strain, EMCC 1931 always produced significantly higher protein amounts in cultivation media than standard strains 2297 and 1593.

The larvicidal activities of the tested strains were performed with toxins produced from different laboratory media; the lethal concentrations were expressed as nanogram of produced protein $/ \mathrm{ml}$. The comparative toxicities of $B$. sphaericus strains produced from five culture media are shown in Figure 10b. It is clearly observed that protein produced by local strains (Bacillus sphaericus EMCC 1931 and EMCC 1932) in P and NYS media was more lethal than that of reference strains (B. sphaericus 1593 and B. sphaericus 2297). The lowest $\mathrm{LC}_{50}$ values of $2.5,3.2,12$ and $13.8 \mathrm{ng} / \mathrm{ml}$ were achieved in poly medium after the $5^{\text {th }}$ day by $B$. sphaericus strains EMCC 1931, EMCC 1932, 1593 and 2297, respectively, against the $3^{\text {rd }}$ instar larvae of Culex pipiens (Figure $10 \mathrm{~b}$ ). However, the $\mathrm{LC}_{50}$ values of 4.4 , 4.8, 6.1 and $7.2 \mathrm{ng} / \mathrm{ml}$ were obtained in NYS medium, in that order.

Significant differences in toxicity against mosquito larvae were observed between $\mathrm{P}$ and NYS media, local (Bacillus sphaericus EMCC 1931, EMCC 1932) and reference (B. sphaericus1593, B. sphaericus 2297) strains. With the rest of media, significant differences were observed between all tested strains and media. The lowest toxicity was observed in LB and AYE media, respectively.

$\mathrm{pH}$ values was in increasing order in all cultivation media as a result of the growth of different strains. The values of final $\mathrm{pH}$ in all tested cultures ranged between 8.4 and 9.0 .

\section{Discussion}

Since the use of locally available effective bacterial strains is always advisable in insect control programs, it should be genetically analyzed to screen the presence of newer or perhaps more toxic stains. The PCR analysis of new isolates provides a valuable prescreen that permits their prioritization for subsequent insect assays.

In the current study, PCR analysis proved that both the standard 1593, 2297 and local EMCC 1931, EMCC1932 strains of B. sphaericus harbor the BinA, $B i n B$ and $M t x 1$ genes encoding Bin A 42-, Bin B 51and Mtx1 100-KDa proteins. This result is in accordance with the information provided for $\operatorname{Bin} A, \operatorname{Bin} B$ and Mtx1 toxin genes Shanmugavelu et al., 1995,; Charles et al., 1996;; Otsuki et al., 1997; and the description of $B$. Sphaericus 2297 and 1593 as highly toxic strains. Binary toxin genes are considered major factors for mosquito larvicidal activity. More recently, Jagtap et al. (2009) proved that the highly toxic B. Sphaericus 2297 and 1593 strains have five toxin genes encoding mosquito larvicidal toxins, namely $\operatorname{BinA}, \operatorname{BinB}, M t x 1, M t x 2$ and Mtx3.

The obtained bioassay results confirmed the superiority of the locally isolated strains compared to the two reference strains with respect to toxicity against mosquito larvae. To assess whether this toxic activity is attributed to a new variant of the bin operon, the amplified PCR products of bin genes were sequenced. Based on bioinformatics analysis, the overall nucleotide and protein similarities veritably indicated that both $B$. sphaericus EMCC 1931 and EMCC 1932 are most similar to B. sphaericus strains 9002, IAB88, IAB872, Lysinobacillus sphaericus ISPC-8, H-25 group and 2297. This result is the same as what previously reported by many authors Aquino de Muro and Priest, 1994,; Bei et al., 2006; Hu et al., 2008.

Toxicity for mosquito larvae has been associated with the formation of toxic proteins during sporulation and/or vegetative growth. As revealed by SDS-PAGE, the local strains (Bacillus sphaericus EMCC 1931 and EMCC 1932) have relatively similar protein profiles (20- to $-139 \mathrm{KDa})$ either during vegetative growth or sporulation with minor exceptions. This finding, to some extent, is in accordance with that obtained early by Baumann et al. (1985),. They found that solubilization of the preparations at $\mathrm{pH} 12$ with $\mathrm{NaOH}$ led to the elimination of all high molecular mass bands but 43- and 63-KDa were not. Other than recently, 


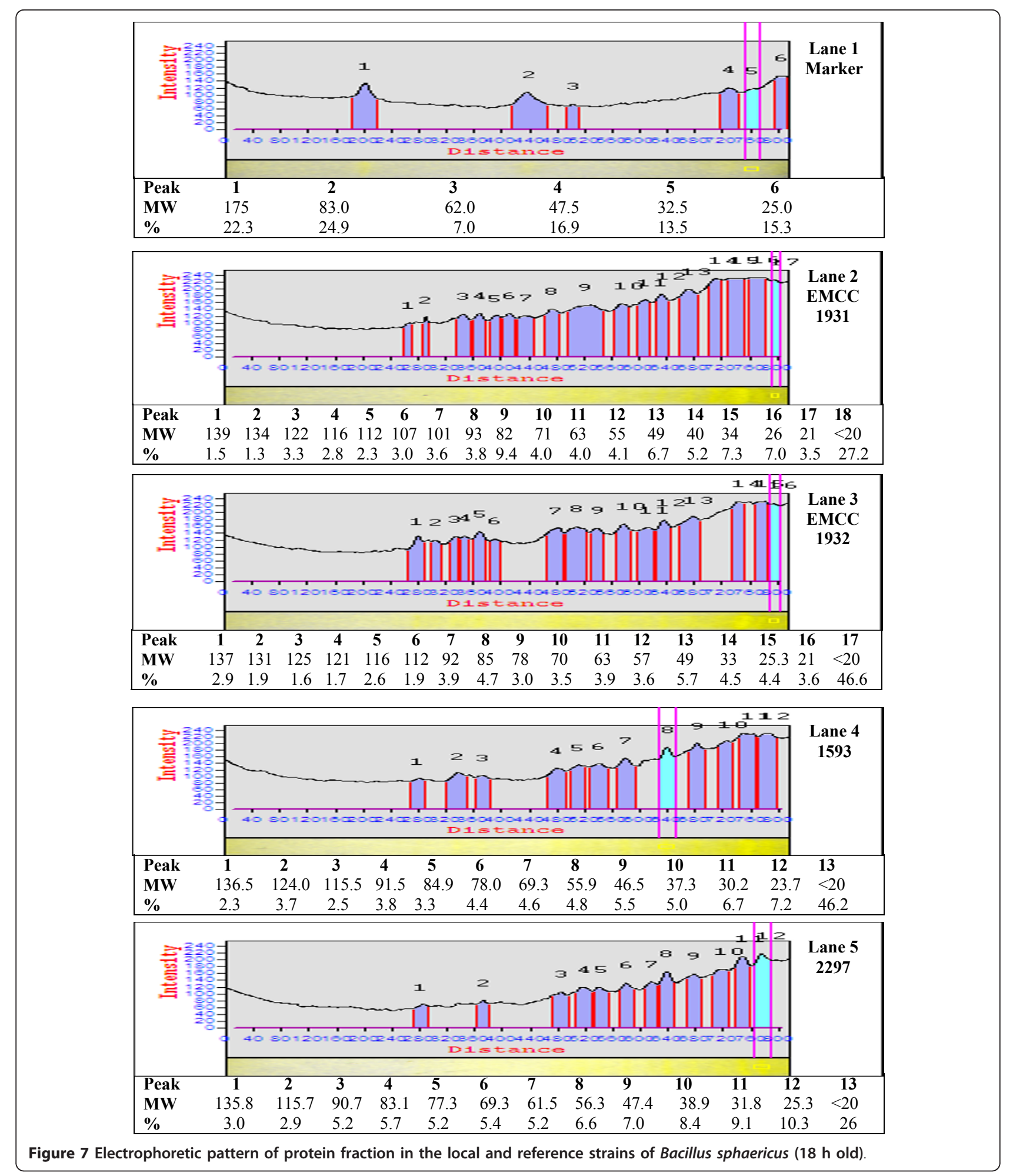

Smith et al. (2005) observed the presence of 110 and 125KDa SDS-PAGE bands from $\mathrm{NaOH}$ extracts of washed $B$. sphaericus spores.

The binary toxin produced by $B$. sphaericus may be synthesized as $110-125-\mathrm{KDa}$ protein which is converted to a non-toxic $63-\mathrm{KDa}$ moiety and a toxic 43-KDa moiety during the process of sporulation. Additional studies have also shown that the 110 - and $125-\mathrm{KDa}$ bands are attributable to the binary toxin by reaction with antibinary toxin antibodies. Also, a $40-\mathrm{KDa}$ protein was 

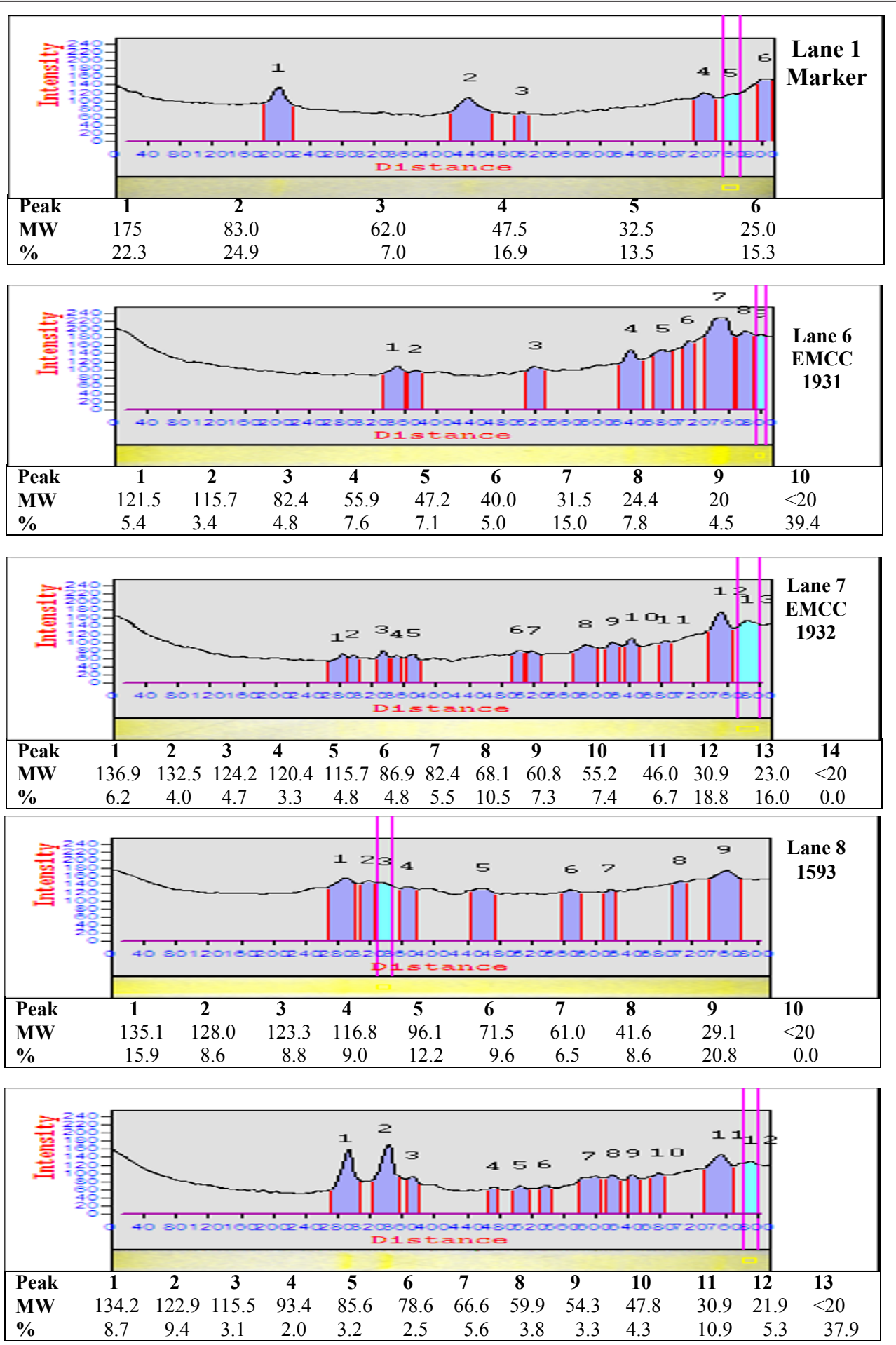

Figure 8 Electrophoretic pattern of protein fraction in the local and reference strains of Bacillus sphaericus ( $120 \mathrm{~h}$ old)

related to 43-KDa toxin Baumann et al., 1985,; Broadwell and Baumann, 1986,; Shanmugavelu et al., 1998,; Smith et al., 2005.

Recently, screening of proteins produced by some toxic isolates of $B$. sphaericus revealed the presence of a $\sim 49 \mathrm{kDa}$ protein in spore/crystal preparations. The absence of this protein in other toxic ones to which mosquito resistance has developed, led to the proposal that this might represent a new toxin that could have an important role in the prevention of insect resistance 


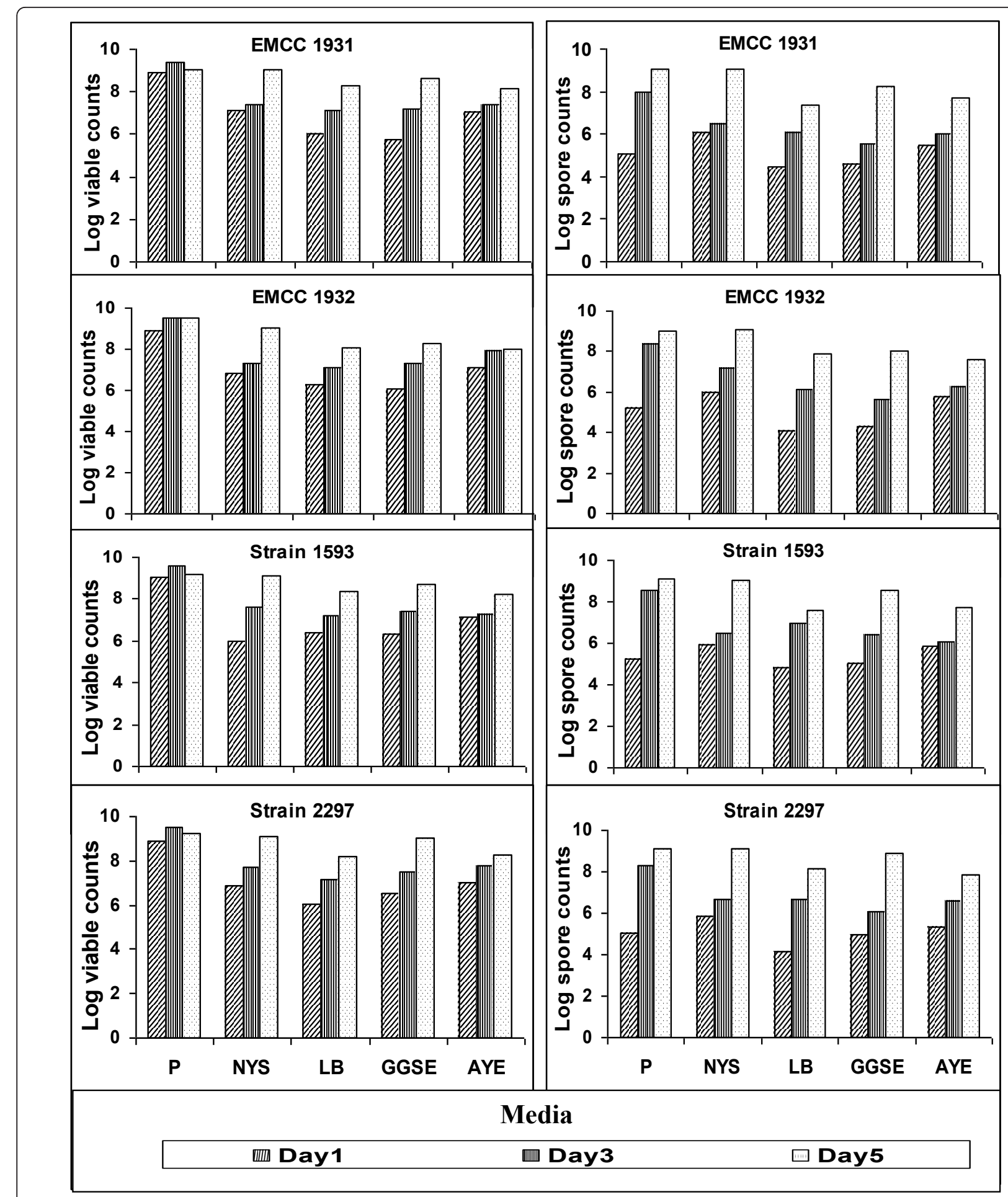

Figure 9 Total viable $\left(\mathrm{LSD}_{0.01}=2.15, \mathrm{CV}=1.43 \%\right)$ and spore $\left(\mathrm{LSD}_{0.01}=1.57, \mathrm{CV}=1.27 \%\right)$ counts of local $(\mathrm{EMCC} 1931, \mathrm{EMCC} 1932)$ and reference $(1593,2297)$ strains of $B$. sphaericus in different conventional laboratory media during cultivation course.

Yuan et al., 2003,; Jones et al., 2007. Our results showed that analysis of protein produced by local strains $B$. sphaericus EMCC 1931 and EMCC 1932 revealed the presence $\sim 49 \mathrm{kDa}$ protein.
Low toxic strains, synthesize toxic proteins during vegetative growth such as 100-, 35.8- and 31-KDa. In the current study, the presence of $100-\mathrm{kDa}$ corresponding to the Mtx1 toxin was observed on SDS-PAGE only 

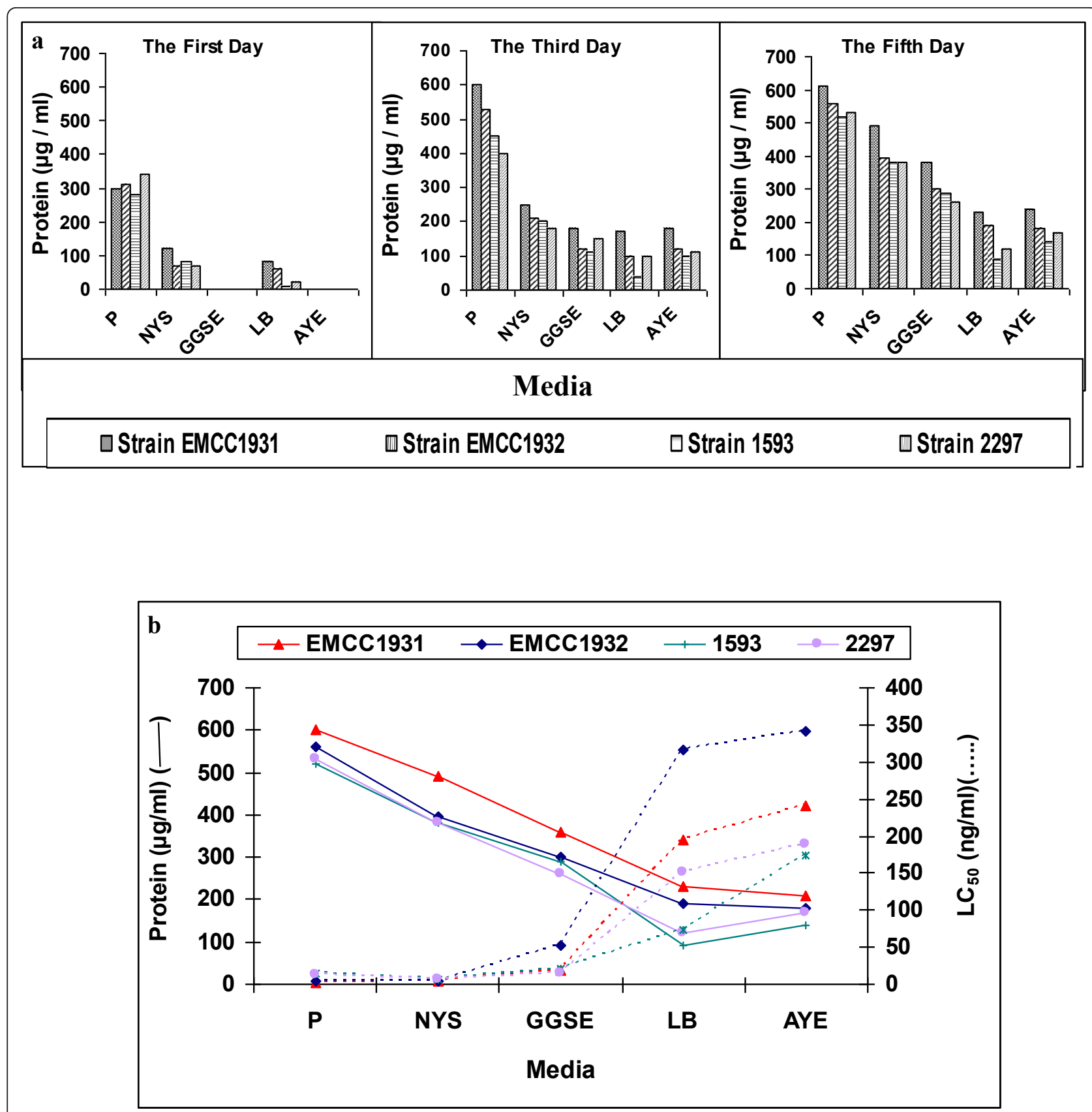

Figure 10 a) Protein synthesis ( $L S D_{0.01}=0.09, \mathrm{CV}=0.02 \%$ ) in the conventional media during the incubation time, b) Relation between protein synthesis $\left(\operatorname{LSD}_{0.01}=2.21, \mathrm{CV}=0.32 \%\right)$ and mosquitocidal activities $\left(\mathrm{LSD}_{0.01}=1.37, \mathrm{CV}=0.68 \%\right)$ of local (EMCC1931, EMCC1932) and reference $(1593,2297)$ strains of $B$. sphaericus at the end of incubation time.

in $18 \mathrm{~h}$ old culture of EMCC1931 but not in $120 \mathrm{~h}$. Furthermore, the visualized bands at 30.2- to 38.9- KDa bands in $18 \mathrm{~h}$ preparations of all strains may be ascribed to the Mtx2 and Mtx3. In the preparations of $120 \mathrm{~h}$, the bands with molecular masses of 30.9- and 31.5-KDa were detected in all strains except B. sphaericus 1593.

Prominently, the Mtx1 has a different mode of action from the binary toxin, and which make it an alternative toxin to delay or overcome development of resistance to binary toxin Wei et al., 2006,. Lately, Rungrod, et al. (2009) demonstrated for the first time that Mtx1 and Mtx2 toxins exhibit synergism against resistant $A$. aegypti mosquito larvae.

From the present results, it is clearly evidenced that media, incubation time and B. sphaericus strains play a key role in growth, sporulation, protein synthesis and 
potency. Prolonging cultivation time up to 5 days actualized the maximum lethal activity and sporulation rate in all media tested. A steady increase in spore counts along the cultivation time was observed. Poly medium proved to be the most auspicious medium for the productivity of $B$. sphaericus.

In literature, the exact cultivation time for obtaining the maximum productivity of $B$. sphaericus strains was conflicting. Some workers found that the maximum level of produced toxins was obtained through $18-24 \mathrm{~h}$ and prolonging cultivation time had never resulted in consistent increase in spore counts or the larvicide yield. However, others observed a progressive increase in sporulation and toxin production with extending incubation time up to $72 \mathrm{~h}$ when $B$. sphaericus cultivated in NYS medium or up to 9 days under semi solid cultivation Myers et al., 1979,; Obeta and Okafor, 1983,; Bourgouin, 1984,; Klein et al., 1989,; Foda et al., 2003,; Prabakaran et al., 2007,; Poopathi and Abdidha, 2007, and 2008.

The presence of larvicidal activity in purified cell wall of B. sphaericus 1593, 2297 have been observed and attributed to the imperfect separation between cell wall and the crystals could account for this phenomenon. At the completion of sporulation and toxin synthesis, the bacterial cells lyse and liberate the spore and the attached toxic parasporal body Myers and Yousten 1980; Yousten et al., 1989,; Klein et al., 2002. This may explain the increasing of toxicity with prolonging cultivation time up to $120 \mathrm{~h}$ in the present work.

The comparison between the tested conventional laboratory media indicated that medium composition has a great effect on the growth, sporulation and biocide production by $B$. sphaericus. P medium was found to be the most propitious medium; the proteins released by local strains (B. sphaericus EMCC 1931 and EMCC 1932) in P medium followed by NYS medium were more lethal than that produced in the other tested media. White and Lotay (1980) investigate the nutritional requirements of 27 strains of B. sphaericus. They found that four strains were grown and sporulated in a simple chemically defined minimal medium, however, the remaining strains needed vitamins or amino acids as well as purine. They also observed that increasing the acetate concentration did not improve growth. Besides, B. sphaericus has several important phenotypic properties, including those of being incapable of carbohydrates utilization and having exclusive metabolic pathways for a wide variety of organic compounds and amino acids Russell et al. 1989,, Alexander and Priest, 1990,; Han et al., 2007.

Such uneven findings in this study may be, in part, due to the variations in the composition of the tested media in their contents of carbon and nitrogen sources as well as minerals; and to the actual nutritional requirements by a certain strain. By grouping the composition of the five reference media tested in the current study, all media except GGSE medium containing at least two organic nitrogen sources of beef extract, peptone and yeast extract; three of them supplemented with glucose, glycerol or acetate as carbon source; some containing sodium chloride while the others containing $\mathrm{Mg}^{2+}, \mathrm{Mn}^{2+}$, $\mathrm{Ca}^{2+}, \mathrm{Fe}^{2+}, \mathrm{Zn}^{2+}$ and potassium phosphates. The calculation of the exact concentrations of carbon and nitrogen $(\mathrm{g} / \mathrm{l})$ in each medium used were found to equal, 8.43, 2.4 in P medium; 2.18, 1.22 in NYS medium; 2.03, 0.3 in GGSE medium; 4.13, 2.1 in LB medium and 3.71, 0.98 in AYE medium, respectively. $P$ medium has the highest concentrations of $\mathrm{C}$ and $\mathrm{N}$ which interprets, in part, the highest yield obtained when all strains were grown in it. The present results gave an idea about the most effective medium that will be used in further study to optimize the biocide production and to develop a low cost effective production medium.

\section{Author details}

'Department of Microbiology, Faculty of Agriculture, Cairo University, Giza 12613, Egypt ${ }^{2}$ Department of Microbiology, National Center for Radiation Research and Technology, Nasr city 11371, Egypt

\section{Authors' contributions}

FMR suggested the research problem and outlined research plan, interpreted the data, prepared the manuscript and have given final approval of the version for publication. All authors, FMR, WDS, MN and HMF, as a research team, carried out the microbiological experiments, bioassay tests and protein estimation, protein profile analysis, DNA extraction matching and submission the sequencing data in the database of gene bank. HMF carried out statistical analysis and figured data. All authors read and approved the final manuscript.

\section{Competing interests}

The authors declare that they have no competing interests.

Received: 19 November 2011 Accepted: 26 January 2012 Published: 26 January 2012

\section{References}

Abbott WS (1925) A method of computing the effectiveness of an insecticide. J Economic Entomology 18:265-267

Alexander B, Priest FG (1990) Numerical classification and identification of Bacillus sphaericus including some strains pathogenic for mosquito larvae. J General Microbiology 136:367-376

Aquino de Muro M, Priest FG (1994) A colony hybridization procedure for the identification of squitocidal strains of $B$. sphaericus on isolation plates. J Invertebrate Pathology 63:310-313. doi:10.1006/jipa.1994.1058.

Baumann P, Unterman BM, Baumann L, Broadwell AH, Abbene SJ, Bowditch RD (1985) Purification of the larvicidal toxin of Bacillus sphaericus and evidence for high molecular weight precursors. J Bacteriology 163:738-747

Bei H, Haizhou L, Xiaomin H, Zhiming Y (2006) Preliminary characterization of a thermostable DNA polymerase I from a mesophilic Bacillus sphaericus strain C3-41. Arch Microbiol 186:203-209. doi:10.1007/s00203-006-0135-3.

Bertani $L$ (1951) Studies on lysogenesis. I. The mode of phage liberation by lysogenic Escherichia coli. J Bacteriology 62:293-300

Bourgouin C, Larget Tl, de Barjac H (1984) Efficacy of dry powders from B. sphaericus RB80, a potent reference preparation for biological titration. J Invertebrate Pathology 44:146-150. doi:10.1016/0022-2011(84)90005-3.

Bradford MM (1976) A rapid and sensitive method for the quantitation of microgram quantities of protein utilizing the principle of protein-dye binding. Analytical Biochemistry 72:248-254. doi:10.1016/0003-2697(76)90527-3. 
Broadwell AH, Baumann P (1986) Sporulation- associated activation of Bacillus sphaericus larvicide. Appl Environmen Microbiol 52:758-764

Carozzi NB, Kramer VC, Warren GW, Evola S, Koziel MG (1991) Prediction of insecticidal activity of Bacillus thuringiensis strains by polymierase chain reaction product profiles. Appl Environmen Microbiol 57:3057-3061

Chan EC, Rutter PJ, Wills A (1973) Abundant growth and sporulation of Bacillus sphaericus NCA Hoop 1-A-2 in a chemically defined medium. Canadian J Microbiology 19:151-154. doi:10.1139/m73-023.

Charles JF, Nielsen-LeRoux C, Delecluse A (1996) Bacillus sphaericus toxins: molecular biology and mode of action. Annual Review of Entomology 41:451-472. doi:10.1146/annurev.en.41.010196.002315.

Fathy HM (2002) Studies on some biocide-producing microorganisms. M. Sc. Thesis, Faculty of Agriculture, Cairo University 274

Foda MS, El-Bendary M, Moharam ME (2003) Salient parameters involved in mosquitocidal toxins production from Bacillus sphaericus by semi-solid substrate fermentation. Egyptian J Microbiology 38:229-246

Han B, Liu H, Hu X, Cai Y, Zheng D, Yuan Z (2007) Molecular characterization of a glucokinase with broad hexose specificity from Bacillus sphaericus strain C341. Appl Environmen Microbiol 73:3581-3586. doi:10.1128/AEM.02863-06.

Hu X, Fan W, Han B, Liu H, Zheng D, Li Q, Dong W, Yan J, Gao M, Berry C, Yuan Z (2008) Complete genome sequence of the mosquitocidal bacterium Bacillus sphaericus C3-41 and comparison with closely related Bacillus species. J Bacteriology 190:2892-2902. doi:10.1128/JB.01652-07.

Jagtap SC, Jagtap CB, Kumar P, Srivastava RB (2009) Detection of Bacillus sphaericus mosquitocidal toxin genes by multiplex colony PCR. Canadian J Microbiology 55:207-209. doi:10.1139/W08-113.

Jones GW, Nielsen-Leroux C, Yang Y, Yuan Z, Vinícius Fiú za Dumas VF, Monnerat RG, Berry C (2007) A new Cry toxin with a unique two-component dependency from Bacillus sphaericus. FASEBJ 21:1412-1420

Klein D, Yanai R, Hofstein R, Fridlender B, Braun S (1989) Production of Bacillus sphaericus larvicide on industrial peptones. Applied Microbiology and Biotechnology 30:580-584

Klein D, Uspensky I, Braun S (2002) Tightly bound binary toxin in the cell wall of Bacillus sphaericus. Appl Environmen Microbiol 68:3300-3307. doi:10.1128/ AEM.68.7.3300-3307.2002.

Laemmli UK (1970) Cleavage of structural proteins during the assembly of the head of bacteriophage T4. Nature 227:680-685. doi:10.1038/227680a0

Litaiff EC, Tadel WP, Porto JIR, Oliveira IMA (2008) Analysis of toxicity on Bacillus sphaericus from Amazon soils to Anopheles darlingi and Culex quinquefasciatus larvae. Acta Amazonica 38:225-262

Myers PS, Yousten AA (1980) Localization of a mosquito-larval toxin of Bacillus sphaericus 1593. Appl Environmen Microbiol 39:1205-1211

Myers P, Yousten AA, Davidson EW (1979) Comparative studies of the mosquito larval toxin of Bacillus sphaericus SSII-1 and 1593. Canadian J Microbiology 25:1227-1231. doi:10.1139/m79-193.

MSTAT-C Version 4 (1987) Software program for the design and analysis of agronomic research experiments. Michigan University, East Lansing, Michigan, USA

Obeta JAN, Okafor N (1983) Production of Bacillus sphaericus strain 1593 primary powder on media made from locally obtainable Nigerian agricultural products. Canadian J Microbiology 29:704-709. doi:10.1139/m83-115.

Otsuki K, Guaycurus TV, Vicente CP (1997) Bacillus sphaericus entomocidal potential determined by polymerase chain reaction. Memorias do Instituto Oswaldo Cruz 92:107-108. doi:10.1590/S0074-02761997000100022.

Poopathi S, Abidha S (2007) Use of feather-based culture media for the production of mosquitocidal bacteria. Biological Control 43:49-55. Cited in http://www.elsevier.com/locate/ibiod. doi:10.1016/j.biocontrol.2007.04.019.

Poopathi S, Abidha S (2008) Biodegradation of poultry waste for the production of mosquitocidal toxins. International Biodeterioration and Biodegradation 62:479-482. Cited in http://www.elsevier.com/locate/ibiod. doi:10.1016/j. ibiod.2008.03.005.

Poopathi S, Anup Kumar K, Kabilan L, Sekar V (2002) Development of low- cost media for the culture of mosquito larvicides, Bacillus sphaericus and Bacillus thuringiensis serovar. israelensis. World J Microbiology \& Biotechnology 18:209-216. doi:10.1023/A:1014937311839.

Prabakaran G, Balaraman K, Hoti SL, Manonmani AM (2007) A cost- effective medium for the large-scale production of Bacillus sphaericus H5a5b (VCRC B42) for mosquito control. Biological Control 41:379-383. doi:10.1016/j. biocontrol.2007.02.004.
Rawlins SC (1989) Biological control of insect pests affecting man and animals in the tropics. CRC Critical Reviews in Microbiology 16:235-252. doi:10.3109/ 10408418909105477.

Russell BL, Jelley SA, Yousten AA (1989) Carbohydrate metabolism in the mosquito pathogen Bacillus sphaericus 2362. Appl Environmen Microbiol 55:294-297

Rungrod A, Tjahaja NK, Soonsanga S, Audtho M, Promdonkoy B (2009) Bacillus sphaericus Mtx1 and Mtx2 toxins co-expressed in Escherichia coli are synergistic against Aedes aegypti larvae. Biotechnol Letters 31:551-555. doi:10.1007/s10529-008-9896-X.

Sambrook J, Fritsch EF, Maniatis T (1989) Molecular cloning laboratory manual. Gold Harbor Laboratory Press, USA1

Sanger F, Nicklen S, Coulson AR (1977) DNA sequencing with chain-terminating inhibitors. Proceedings of the National Academy of Sciences of the United States of America 74:5463-7. doi:10.1073/pnas.74.12.5463.

Sasaki K, Jiaviriyaboonya S, Rogers PL (1998) Enhancement of sporulation and crystal toxin production by corn-steep liquor feeding during intermittent fedbatch culture of Bacillus sphaericus 2362. Biotechnology Letters 20:165-168. doi:10.1023/A:1005332609136.

Shanmugavelu M, Rajamohan F, Kathirvel M, Elangovan G, Dean DH, Jayaraman K (1998) Functional complementation of non toxic mutant binary toxins of Bacillus sphaericus $1593 \mathrm{M}$ generated by sitedirected mutagenesis. Appl Environmen Microbiol 64:756-759

Shanmugavelu M, Sritharan V, Jayaraman K (1995) Polymerase chain reaction and non- radioactive gene probe based identification of mosquito larvicidal strains of Bacillus sphaericus and monitoring of B. sphaericus $1593 \mathrm{M}$, released in the environment. J Biotechnology 39:99-106. doi:10.1016/0168-1656(94) 00145-3.

Smith AW, Camara-Artigas A, Brune DC, Allen JP (2005) Implications of highmolecular-weight oligomers of the binary toxin from Bacillus sphaericus. J Invertebrate Pathology 88:27-33. doi:10.1016/j.jip.2004.10.005.

Wei S, Cai Q, Yuan Z (2006) Mosquitocidal toxin from Bacillus sphaericus induces stronger delayed effects than binary toxin on Culex quinquefasciatus (Diptera: Culicidae). J Medical Entomology 43:726-730. doi:10.1603/0022-2585(2006)43 [726:MTFBSI]2.0.CO;2.

White PJ, Lotay H (1980) Minimal nutritional requirements of B. sphaericus NCTC 9602 and other strains. J General Microbiology 118:13-19

Yousten AA, Russell BL, Davidson EW, Faust RM, Margalit J, Tahori AS (1989) Factors affecting fermentative production of Bacillus sphaericus. Israel J Entomology 23:233-238

Yousten AA, Davidson EW (1982) Ultrastructural analysis of spores and parasporal crystals formed by Bacillus sphaericus 2297. Appl Environmen Microbiol 44:1449-1455

Yuan ZM, Pei GF, Regis L, Nielsen-Leroux C, Cai QX (2003) Cross- resistance between strains of Bacillus sphaericus but not $B$. thuringiensis israelensis in colonies of the mosquito Culex quinquefasciatus. Med Vet Entomol 17:251-256. doi:10.1046/j.1365-2915.2003.00429.x.

Yuan Z, Zhang YM, Cai QX, Liu EY (2000) High-level field resistance to Bacillus sphaericus C3-41 in Culex quinquefasciatus from Southern China. Biocontrol Sci Techn 10:41-49. doi:10.1080/09583150029378.

\section{doi:10.1186/2191-0855-2-9}

Cite this article as: Rashad et al:: Identification of mosquito larvicidal bacterial strains isolated from north Sinai in Egypt. AMB Express 2012 2:9.

\section{Submit your manuscript to a SpringerOpen ${ }^{\circ}$ journal and benefit from:}

- Convenient online submission

- Rigorous peer review

- Immediate publication on acceptance

- Open access: articles freely available online

- High visibility within the field

- Retaining the copyright to your article

Submit your next manuscript at $\boldsymbol{~ s p r i n g e r o p e n . c o m ~}$ 